\title{
Smoking Phenomenon Among Elementary Children in Pasuruan - East Java
}

\author{
Akhtifa Dwi Kurliati*, Laurens Kaluge, Ninik Indrawati, Waluyo Edi Susanto \\ Graduate Program of Social Studies Education \\ Universitas Kanjuruhan Malang \\ Malang, Indonesia \\ *mommy.iefa@gmail.com
}

\begin{abstract}
This study aimed at describing the phenomenon of children at elementary-age who actively smoked. Using a qualitative study type, students, head of school, and student parents as the key informants were approached. The process of data collection was done by interviews, observations and searching student documents. The obtained data were analyzed by using an interaction model from Miles and Huberman. The results discovered that the causes of elementary school children smoking were the influences of environment that facilitated them. The impacts of smoking were relaxation, coughing and addiction. The efforts of the school to deter such negative effects by promoting character education and repressing actions through light physical punishment and parental involvement. Mostly, the response of parents related to students smoking was to assess the degree of deviation, conduct special policies such as rationalizing and controlling relationships.
\end{abstract}

Keywords—smoking, children, elementary school

\section{INTRODUCTION}

Children are living with high curiosity. It's no wonder they would do anything through, namely observing and imitating for their identity. The environmental factors have critical roles in shaping children's identity. If they pass well the childhood phase, in conducive environment, there will be big tendencies for them to grow up optimally for healthy spirit and ideal personality $[1,2]$. Social environment may bring and demonstrate bad influences for children to deviant behaviors. One sort of deviants is smoking. This behavior is deviant for children, but may not be for adults who have already worked and do as means of recreation and entertainment [3].

Nowadays there are many smoking children. Yunita [4] reported that there were seven out of nine students who were active smokers in a respective elementary school. The causes could be from various factors. This behavior was also unsettling for many parties, especially parents and educational practitioners. This symptom needs to be studied further to eliminate the deviation. Therefore the focus of this study was children under seventeen year old since above that age would be considered as adults. In addition, the immature age, especially at the elementary school level, was the age of compulsory education that has not worked yet so the financial needs could not be fulfilled. Also children who smoked were problematic for education, because they did not perform positive character properly dealing with their peers.

A study of smoking behavior research was conducted by Hakiki [5] whose study focus on the factors that cause children to smoke. It was found that the cause was from the environment and the child's self. This study focused on children between ten and twelve years of age. Purnomo [6] also examined the relationship between several variables in students' smoking behavior. The results show that the smoking behavior of students was influenced by gender, knowledge about cigarettes, attitudes towards smoking, the amount of pocket money and the presence of family members who smoke.

Other study conducted by Rachmat, Thaha, Syafar [7] on the smoking behavior of junior high school adolescents. They found that smoking behavior was strongly influenced by peer group interactions, family interactions, cigarette advertisements, and attitudes with adolescent smoking behavior. These findings were supported by research by Alamsyah and Nopianto [8] on the determinants of smoking behavior in adolescents. It was found that the determinants of smoking behavior were knowledge about cigarettes, attitudes towards smoking, extracurricular activities in schools and cigarette advertisements. In the international realm, Maggi, Lovato, Hilh, Johnson, Ratner, and Shovelle [9] conducted a study on adolescents' perceptions of parental influences on their smoking behaviors. They also found the large role of parents in children's smoking behaviors. If parents were not wise, children would smoke and vice versa.

The difference between this study and previous research was that this study would reveal more about the causes, impacts and efforts of the school in overcoming the problem of elementary school smoking children. The social sciences perspectives, as used here, were different from previous studies which emphasizing on health, chemistry, and visual communication design perspectives. So, based on the description of this introduction, the researcher explored the 
phenomenon of smoking among elementary school children which seemed prevalent in the District of Pasuruan, East Java.

\section{METHODS}

The approach used in this study was qualitative research. This study sought to explain scientifically the phenomena experienced by subjects [10]. Basically, the qualitative approach did not use a statistical approach in understanding a problem. The type of research used was grounded theory due to empirical experiences in the field and deductive concepts [11].

This study was conducted for three months since the researcher had already familiarized with the field. The setting was a public elementary school in Lebakrejo Village, District of Pasuruan. This school represented other schools in the district in terms of the number and characteristics of teaching resources, facilities, characteristics of students and their parents. In this school there were many smoking students so it was not difficult to find the informants who met the study requirements.

The subjects were five elementary school children who were accustomed to smoking. Information about a student's smoking was known from cases that had been experienced by students, as well as data from informants. The principal was also an informant, as the main policy officer in the school where the research was conducted. The researcher was also digging data from the parents of smoking students to know their perceptions and attitudes.

The study procedures were divided into pre-field, field, and post-field stages. At the beginning, the pre-field was carried out by selecting research topics. Themes were selected based on data in the field. As the preliminary step, the actions were observing the smoking behavior of the students, as well as looking for basic information related to research themes. Then it proceeded to the main research. The stage in the field was carried out by searching for data, processing, analyzing and drawing conclusions both temporarily and finally on the research data. The post-field stage was the stage of writing a research report in the form of this article.

Data were differentiated between primary and secondary. The primary data obtained from direct accounts of the perpetrators, while secondary data were supporting data in the form of photographs and records. The data in this study were obtained by means of interviews, observation, and documentation. The interview was an oral interaction activity between the interviewer and the resource person to find data to be used for research. Observation was an activity that required researchers to go directly to the field to observe space, time, actions, actors, and objects that supporting research [12]. Another data collection technique was tracing the school archives.

An interactive model was used in order to analyze data. The interactive qualitative data analysis was carried out continuously until the saturation of the data were obtained [13]. This model built relationships between each part and was flexible. So, if there was a block or deficiency in one part, it could move to other stages easily.

\section{RESULTS AND DISCUSSION}

Five main themes covered the findings. They themes were the causes of smoking, sense of craving, impact of smoking, school efforts, and parental involvement. These were meaningful and discussed shortly as follows.

\section{A. The Causes of Smoking}

It was revealed that elementary school children who smoke were influenced by three factors. First, was the imitation process. Second was high curiosity. And the third was environmental factors. These three causes had mutual effects each other. This process of smoking happened because children wanted to know what they enjoyed from the object they imitated. It was sort of trial and error. Gradually it created an addiction, then there would be sustainability $[14,15]$. Those three factors confirmed that children's smoking behavior expressed the implementation of child developmental empiricism theory. According to empiricism, humans were "tabula rasa" or papers without any content, it was experience from outside that makes the paper full [16].

An activity could be a form of human social interaction. This was based on the opinion that imitation behaviors were forms of social interaction carried out by humans [17]. There would be times when humans wanted to imitate what they saw, heard or thought. Smoking behavior was a form of imitation of behavior obtained from the process. Children were individuals who did not have a proper filter to distinguish between the good and the bad of an action. Children did not necessarily think further about the consequences of the actions they imitated, their needs and desires personally [18].

Furthermore, the smoking behavior of children was also caused by the factor of trials. They were individuals [19] and curiously to experience a lot of new things. The point was to solve their curiosity. When this curiosity was fulfilled, there were two possibilities that would happen, namely done again or abandoned. Cigarettes contained nicotine which made the users additive [20].

\section{B. Arising the Sence of Craving Continuously}

Another cause was due to environmental factors. The environment could come from the place where they lived such as family, neighbors around the house, and so on. Family had a dominant role in influencing children's smoking behavior [7,9,21]. There were also peers both from schools and other bonding institutions. When a child lived among smokers, there was a strong possibility to imitate the same thing. The factors that caused children to smoke were in accordance with the results of research from Hakiki [5] which discovered the effects from outside and inside of the group.

Smoking behavior in children could be categorized as a social deviation. this was based on the characteristics of social 
deviation itself $[17,22]$. Social deviation was something that could be identified as breaking the rules where the deviation was. In addition, smoking behavior was also seen as deviant because it did not show synchronization between the social values and the personal behaviors. The ideal culture or social values required school children to avoid smoking but in fact not so.

Smoking behaviors at school were entirely dominated by boys. This showed that men were more prone to deviant behavior than women. Rizal [23] stated that the condition of women's morality was better in the realm of schools. The reason was based on the attitude assessment carried out, and the performance of women was better than that of men. Indeed, Kurnela [24] emphasized that most men who smoke did not think about the future impact.

\section{The Impact of Smoking}

There were two effects of smoking on children i.e., positive and negative. Calm and relaxation were positive effects that obtained by children, because smoking activities were carried out while relaxing. Thus, it created a sensation for the perpetrators. In addition, back to the nature of cigarettes contained addictive substances. Addictive substances were able to provide certain sensations to its users [25,26].

The negative impact of smoking had not been felt significantly by children. It was found that the impact was only minor complaints such as light coughing or shortness of breath for a moment. This was because the frequency of smoking by children was shorter than that of parents, so that they had not felt severe impact of smoking. The reason was the far age distance from their parents, so that the number of cigarettes they smoke was still less than their parents [27]. As a result, harmful substances that enter their bodies were still at a low level.

\section{The School Efforts}

The school's efforts to deal with smoking children were divided into two types, namely prevention and enforcement. Prevention efforts were carried out by customizing positive values at students, either directly or indirectly. A teacher was the central motor in instilling positive values for students at school [28]. Positive values were useful in preventing deviant behaviors so that conditions were maintained in harmony [29].

The action was carried out by warning and applying light physical punishment. These were forms of overcoming deviant behaviors, which deterred the negative effects on the perpetrators. However, there were obstacles that were often faced, because the school received protests from parents for physical acts committed against their children. If the smoking behavior was carried out secretly and not wearing a uniform, it was considered to be outside of school. Schools could not and did not had the right to take care of children's outside the school time. School regulations only applied when the child was at school hours. In essence, schools had the authority to apply discipline to the rules of their students [30].

\section{E. Parental Efforts}

Family was the primary group owned by a child. In each family the main components were children and parents. Parents were parties who had full authority over children. The role of parents was a central figure in dealing with smoking children. Parents had a role in preventing children from doing negative actions [31]. The role of parents was to advise their child who smokes. In addition, there were also thoughts of parents who let them. This omission was a form of action taken when the expected behavior of the parents was difficult to fulfill. When given advice, even physical treatment was not able to change the child's condition, so neglect was the last resort. The thinking about smoking behavior was still a fairly normal deviation, not as critical as stealing, drunkenness, or other forms of deviance. This meant that smoking behavior in children was a deviant behavior that was still acceptable [17]. Although neglect could also had a severe impact on deviant behavior in the future [32].

Even though allowing to smoke, there were still efforts to make this behavior still in an adequate level [33]. The effort needed to do rationing. The rationing was done so that the number of cigarettes smoked by children would be gradually reduced. In addition, rationing also disciplined children financially.

As for other efforts made by parents was to maintain the communication between the child and his friends or companion. It was known that the peer environment was one of the causes of children smoking. As much as possible, parents supervised the companion group with whom he played, what he did when he played, or limited his playing hours [26,32]. In this way the family performed its protective function for children.

\section{CONCLUSION}

Smoking behaviors among elementary school children were categorized as forms of deviant behavior. These behaviors were caused by the child and the environmental factors. The factors of child side were curiosity, trial and error. Meanwhile, the environmental factors were come from family, neighbors, or friends. The positive impact of children's smoking behaviors were able to provide relaxation. Meanwhile, the negative impact was limited to minor complaints such as coughing and shortness of a moment. In dealing with smoking children, schools should take precautions and actions. Prevention was through familiarizing the positive values and character education. Meanwhile, the action could be in the form of warning, parental summons and involvement, or light physical punishment. On the other hand, the efforts of parents in dealing with smoking children were by giving advices, applying special rules, and keeping children socially.

\section{REFERENCES}

[1] N.A. Laila, "Peran lingkungan terhadap optimalisasi perkembangan bahasa anak usia dini," Mu'adalah: Jurnal Studi Gender dan Anak, vol. 1 , no. 1 , pp. $71-80,2013$. 
[2] Suryani, "Prespektif Perilaku Menyimpang Anak Remaja: Studi Berbagai Masalah Sosial," Jurnal Sulesana, vol. 8, no. 1, pp. 119-131, 2013.

[3] T. Salawati dan R. Amalia, "Perilaku merokok di kalangan mahasiswa Universitas Muhammadiyah Semarang (Smoking behaviour among students in UNIMUS_," in Prosiding seminar nasional \& internasional, Semarang, 2010: Universitas Muhammadiyah Semarang.

[4] C.L. Junita, "Ironis, 7 dari 9 Anak Kelas 5 di Sebuah SD Merokok Secara Aktif," 2019. [Online] Retrieved from: www.kompasiana.com [Accessed on: 20 May 2020].

[5] M.I. Hakiki, Faktor-Faktor Penyebab Perilaku Merokok pada Anak Usia 10-12 Tahun. Disertasi Doktor, Malang: Universitas Negeri Malang, 2015.

[6] B.I. Purnomo, Hubungan Faktor Predisposisi, Faktor Pemungkin, dan Faktor Penguat dengan Perilaku Merokok Pelajar di SMKN 2 Kota Probolinggo Tahun 2017. Skripsi, Malang: FIK Universitas Negeri Malang, 2017.

[7] M. Rachmat, R.M. Thaha, dan M. Syafar, "Perilaku Merokok Remaja Sekolah Menengah Pertama," Kesmas: Jurnal Kesehatan Masyarakat Nasional, vol. 7, no. 11, pp. 502-508, 2013.

[8] A.N. Alamsyah, "Determinan Perilaku Merokok pada Remaja," Jurnal Endurance, vol. 2, no. 1, pp. 25-30, 2017.

[9] S. Maggi, Y.C. Lovato, E.M. Hilh, L.J. Johnson, P.A. Ratner, and J.A. Shovelle, "Adolescents' Perceptions of Parental Influences on Their Smoking Behavior: A Content Analysis," Sage Journal, vol. 46, no. 1, pp. 132-149, 2014.

[10] L.J. Moleong, Metode penelitian kualitatif. Bandung: Remaja Rosdakarya, 2016.

[11] W. Walidin dan S. Idris, Metodologi penelitian kualitatif \& grounded theory. Banda Aceh: FTK Ar-Raniry Press, 2015.

[12] H. Patilima, Metode Penelitian Kualitatif. Bandung: Alfabeta, 2007.

[13] B.M. Miles dan M. Huberman, Analisis Data Kualitatif Buku Sumber Tentang Metode-Metode Baru. Jakarta: UIP, 2014.

[14] D.K. Cortese, G. Szczypka, S. Emery, S. Wang, E. Hair, and D. Vallone, "Smoking selfies: using instagram to explore young women's smoking behaviors," Social media + society, vol. July-September, pp. 1-8, 2018.

[15] S. Martini and M. Sulistyowati, The determinants of smoking behavior among teenagers in East Java Province, Indonesia. Washington, D.C The International Bank for Reconstruction and Development, The World Bank, 2005.

[16] T. Pigot-Upshall, "How standardization and bahaviorism foster inequality in public education: a comparative experience," One world, vol. 4, no. 1, pp. 11-19, 2017.

[17] E.M. Setiadi dan U. Kolip, Pengantar Sosiologi Pemahaman Fakta dan Gejala Permasalahan Sosial: Teori, Aplikasi, dan Pemecahannya. Jakarta: Prenadamedia, 2015.
[18] A. Nawawi, "Pentingnya Pendidikan Nilai Moral bagi Generasi Penerus," INSANIA: Jurnal Pemikiran Alternatif Kependidikan, vol. 16, no. 2, pp. 119-133, 2011.

[19] S. Yumnah, "Kecerdasan Anak Dalam Pengenalan Potensi Diri," Jurnal Studi Islam: Pancawahana, vol. 11, no. 2, pp. 30-50, 2016.

[20] A. Aji, L. Maulinda, dan S. Amin, "Isolasi Nikotin Dari Puntung Rokok Sebagai Insektis," Jurnal Teknologi Kimia Unimal, vol. 4, no. 1, pp. 100-120, 2017.

[21] K. Cahyo, P.A. Wigati, dan Z. Shaluhiyah, "Rokok, Pola Pemasaran dan Perilaku Merokok Siswa SMA/Sederajat di Kota Semarang," Media Kesehatan Masyarakat Indonesia, vol. 11, no. 1, pp. 75-84, 2012.

[22] S. Nisrima, M. Yunus, dan E. Hayati, "Pembinaan Perilaku Sosial Remaja Penghuni Yayasan Islam Media Kasih Kota Banda Aceh," Jurnal Ilmiah Mahasiswa Pendidikan Kewarganegaraan, vol. 1, no. 1, 2016.

[23] Y. Rizal, "Perilaku Moral Remaja dalam Perspektif Budaya," JOMSIGN: Journal of Multicultural Studies in Guidance and Counseling, vol. 1, no. 1, pp. 35-44, 2017.

[24] S. Kurnela, "Hubungan Antara Tingkat Stres Dengan Perilaku Merokok Di SMA Santun Untan Pontianak," Jurnal ProNers, vol. 1, no. 1, 2014.

[25] C. Ahalat, T. Buisker, J. Myers, and B. Williams, "Smoking and smoking cessation among criminal justice - involved older adults," Tobacco use insights, vol. 12, no. 1, pp. 1-9, 2019.

[26] B. Smet, L. Maes, L.d. Clercq, K. Haryanti, and R.D. Winarno, "Determinants of smoking behavior among adolescents in Semarang, Indonesia," Tobacco Control, vol. 8, no. 1, pp. 186-191, 1999.

[27] W. Ruiping, J. Yonggen, L. Xin, Z. Qi, Z. Meijing, G. Ying, and Z. Genming, "Relationship between smoking duration, smoking intensity, hypothetical tobacco price increases, and smoking habit hange intension among current smokers in Shanghai," Iternationnal medical research, vol. 47 , no. 10 , pp. 5216-5228, 2019.

[28] S. Sauri, "Membangun karakter bangsa melalui pembinaan profesionalisme guru berbasis pendidikan nilai," Jurnal Pendidikan Karakter, vol. 2, no. 2, pp. 1-15, 2010.

[29] M. Hariyani, M. Mudjiran, dan Y. Syukur, "Dampak Pornografi Terhadap Perilaku Siswa dan Upaya Guru Pembimbing untuk Mengatasinya," Konselor, vol. 1, no. 2, 2012.

[30] R. Meyanti, "Peran Guru dalam Penerapan Disiplin Siswa SMA," Jurnal Pendidikan dan Pembelajaran, vol. 6, no. 8, 2017.

[31] I. Rakhmawati, "Peran keluarga dalam pengasuhan anak," Bimbingan Konseling Islam, vol. 6, no. 1, pp. 1-18, 2015.

[32] W. Winarsih, W. Kusumawati, and Anjarwati, "The correlation between family smoking habits and mosquito coils use with pneumonia incidences in toddlers," Journal of health technology assessment in midwifery, vol. 2, no. 2, pp. 69-74, 2019

[33] W. Septiono and D.W. Meyrowitsch, "Family role towards smoking behaviour among children in Jakarta," Jurnal kesehatan masyarakat nasional, vol. 9, no. 1, pp. 58-63, 2014. 